\title{
WALORY INFORMACYJNE SPRAWOZDANIA FINANSOWEGO JEDNOSTEK MIKRO
}

\begin{abstract}
Wynik finansowy jest podstawowym miernikiem efektywności prowadzenia działalności gospodarczej. Aby skutecznie zarządzać wynikiem finansowym niezbędne są informacje na temat elementów wpływających na jego postać i zmiany. Tymi informacjami są informacje dotyczące przychodów i kosztów. Zakres merytoryczny kont księgowych jest często zdeterminowany potrzebami sprawozdawczymi. A zatem o tym co jest ewidencjonowane na kontach księgowych decyduje często postać sprawozdań finansowych, które zobowiązana jest sporządzać dana jednostka gospodarcza. Również osoby, które są osobami z zewnątrz, a są zainteresowane informacjami o sytuacji finansowej, wynikach działalności oraz zmianach sytuacji finansowej jednostki gospodarczej są skazane na korzystanie $\mathrm{z}$ tych informacji, które dana jednostka im przekaże. Syntetycznym zestawieniem elementów kształtujących wynik finansowy jest sprawozdanie finansowe. Zadaniem sprawozdań finansowych jednostek gospodarczych jest informowanie zainteresowanych podmiotów i osób o sytuacji finansowej, wynikach działalności oraz zmianach sytuacji finansowej jednostki gospodarczej. Nowelizacja ustawy o rachunkowości wprowadziła pojęcie jednostki mikro i nowy uproszczony wzór sprawozdania finansowego dla tego typu jednostek. Zmiana ta ma na celu dostosowanie szczegółowości informacji prezentowanych $\mathrm{w}$ sprawozdaniu finansowym do rozmiarów prowadzenia działalności gospodarczej. Sprawozdana finansowe mikro jednostek są mocno uproszczone. Powoduje to istotny spadek walorów informacyjnych tych sprawozdań. Problemem, który się pojawia jest możliwość zaspokojenia potrzeb informacyjnych różnych adresatów takich sprawozdań finansowych. Celem artykułu jest poddanie krótkiej analizie zakresu ujawnień informacji zawartych w sprawozdaniach finansowych mikrojednostek i ich wykorzystaniu do celów zarządczych.
\end{abstract}

Słowa kluczowe: sprawozdanie finansowe, mikro jednostka, rachunkowość.

\section{WPROWADZENIE}

Jednostki gospodarcze działające na rynku, niezależnie od skali prowadzonej działalności gospodarczej za główny swój krótkoterminowy cel uważają zysk finansowy, a w długim czasie - wzrost wartości przedsiębiorstwa dla właścicieli. Funkcję celu dotyczącego maksymalizacji zysku można przedstawić za pomocą wzoru:

$$
W F \quad=P-K \rightarrow \text { maksimum }
$$

gdzie:

$W F$ - wynik finansowy,

$P$ - przychody z działalności gospodarczej,

$K$ - koszty prowadzenia działalności gospodarczej.

1 Dr inż. Grzegorz Lew, Zakład Finansów i Bankowości, Wydział Zarządzania, Politechnika Rzeszowska, ul. Powstańców Warszawy 8, 35-959 Rzeszów, tel. (017) 865-19-14, e-mail: lewgrzes@prz.edu.pl 
W celu maksymalizacji wartości zysku przedsiębiorstwa optymalizują w procesach zarządczych wartości przychodów (starając się je maksymalizować) i kosztów (starając się je minimalizować). W celu zarządzania tymi zmiennymi przedsiębiorstwa potrzebuja wiarygodnych, rzetelnych i aktualnych informacji zarówno o przychodach, jak i kosztach uzyskiwanych lub ponoszonych podczas działań, które wykonują w trakcie prowadzenia działalności gospodarczej.

Kluczową rolę w przekazywaniu niezbędnych informacji potrzebnych do zarządzania przychodami i kosztami, a co za tym idzie - wynikiem finansowym odgrywa rachunkowość finansowa. „Produktem finalnym” rachunkowości finansowej są sprawozdania finansowe, które w sformalizowany sposób komunikuja podmiotom i osobom zainteresowanym dane na temat sytuacji finansowej, wyników działalności oraz zmian sytuacji finansowej jednostki gospodarczej.

Dzięki temu, że przy sporządzaniu sprawozdań finansowych przestrzega się ustalonych $w$ przepisach prawnych zasad, można je również wykorzystać do porównywania ${ }^{2}$ sytuacji finansowej, wyników działalności oraz zmian sytuacji finansowej różnych jednostek działających w interesującym ich użytkowników segmencie rynku lub branży. Sprawozdanie finansowe jest narzędziem pozwalającym na szybką analizę danych finansowych, które przedstawia w uporządkowany, syntetyczny sposób. Konstrukcja sprawozdań finansowych zdeterminowana jest wymogami prawnymi zawartymi zarówno w regulacjach krajowych, jak i międzynarodowych.

W praktyce istnieje wielu adresatów informacji zawartych w sprawozdaniach finansowych jednostek gospodarczych. Przede wszystkim są to podmioty zewnętrzne, takie jak: urząd statystyczny, urzędy skarbowe, samorządy lokalne, banki, potencjalni i obecni inwestorzy oraz interesariusze wewnętrzni, czyli właściciele i zarządzający tymi jednostkami. W większości wypadków zgłaszają oni zapotrzebowanie na informacje o relatywnie dużym poziomie agregacji, prezentujące w syntetyczny sposób potrzebne im informacje.

W celu zaspokojenia podstawowych potrzeb informacyjnych, zwłaszcza zewnętrznych adresatów, wystarczające są sprawozdania finansowe, których zawartość merytoryczna przedstawiona jest $\mathrm{w}$ załączniku 1 do ustawy o rachunkowości ${ }^{3}$. Środowisko polskich przedsiębiorców ciaggle postuluje o upraszczanie przepisów regulujących zasady prowadzenia działalności gospodarczej w Polsce. Ustawodawca, wychodząc naprzeciw tym postulatom, co jakiś czas wprowadza różne zmiany w polskim prawie gospodarczym, które mają „ułatwić życie” przedsiębiorcom. Niestety spora część tych zmian ma charakter ilościowy, a nie jakościowy, co dzięki weryfikacji tych zmian w praktyce można określić mianem ,psucia”, w różnym rozumieniu tego słowa, prawa.

W roku $2014 \mathrm{w}$ ustawie o rachunkowości wprowadzono pojęcie jednostki mikro (mikrojednostki ${ }^{4}$ ) i $\mathrm{w}$ konsekwencji tego wprowadzono pewne uproszczenia ich

${ }^{2}$ Sprawozdanie finansowe wedtug polskich i międzynarodowych standardów rachunkowości, red. G.K. Świderska, W. Więcław, Difin, Warszawa 2012, s. 60.

${ }^{3}$ Ustawa z 29 września 1994 r. o rachunkowości DzU 2013, poz. 330 ze zm.

${ }^{4}$ Według Dyrektywy Parlamentu Europejskiego i Rady 2013/34/UE z 26 czerwca 2013 r. w sprawie rocznych sprawozdań finansowych, skonsolidowanych sprawozdań finansowych i powiązanych sprawozdań niektórych rodzajów jednostek, zmieniającą dyrektywę Parlamentu Europejskiego i 
dotyczące. Podstawową zmianą było wprowadzenie załącznika 4 do tej ustawy określającej postać uproszczonego sprawozdania finansowego dla tego typu jednostek gospodarczych.

Celem artykułu jest poddanie krótkiej analizie zakresu ujawnień informacji zawartych w sprawozdaniach finansowych mikrojednostek i ich wykorzystaniu do celów zarządczych. W tym wypadku $\mathrm{z}$ celem zarządczym wykorzystania sprawozdania finansowego mamy do czynienia $w$ sytuacji inicjowania podejmowania decyzji na podstawie informacji zawartych w tym sprawozdaniu finansowym. Od jakości i sposobu prezentacji informacji $\mathrm{w}$ sprawozdaniu finansowym uzależniona jest forma decyzji podjętych na podstawie tych informacji.

\section{POJĘCIE MIKRO JEDNOSTKI W REGULACJACH PRAWNYCH}

Definicja mikrojednostki w uregulowaniach międzynarodowych zawarta jest w Dyrektywie Parlamentu Europejskiego i Rady 2013/34/UE ${ }^{5}$. Artykuł 3, ust. 1 dyrektywy określa mikrojednostki jako jednostki, które na dzień bilansowy nie przekraczają limitów w przypadku co najmniej dwóch z trzech następujących kryteriów:

a) suma bilansowa: 350000 euro,

b) przychody netto ze sprzedaży: 700000 euro,

c) średnia liczba zatrudnionych w roku obrotowym: 10 osób.

Z kolei ustawa o rachunkowości ${ }^{6}$ w swoim art. 3, ust. 1a pod pojęciem mikrojednostki rozumie:

1) spółki handlowe, z wyłączeniem wymienionych w art. 2, ust. 1, pkt. 2, jeżeli w roku obrotowym, za który sporządzają sprawozdanie finansowe, oraz w roku poprzedzającym ten rok obrotowy, a w wypadku jednostek rozpoczynających działalność w roku obrotowym, w którym rozpoczęły działalność, nie przekroczyły co najmniej dwóch z następujących trzech wielkości:

a) $1500 \quad 000 \mathrm{zł}$ - w wypadku sumy aktywów bilansu na koniec roku obrotowego,

b) 3000000 zł - w wypadku przychodów netto ze sprzedaży towarów i produktów za rok obrotowy,

c) 10 osób - w wypadku średniorocznego zatrudnienia w przeliczeniu na pełne etaty,

2) stowarzyszenia, związki zawodowe, organizacje pracodawców, izby gospodarcze, fundacje, przedstawicielstwa przedsiębiorców zagranicznych, w rozumieniu przepisów o swobodzie działalności gospodarczej, społeczno-zawodowe organizacje rolników, organizacje samorządu zawodowego, organizacje samorządu gospodarczego rzemiosła i Polskie Biuro Ubezpieczycieli Komunikacyjnych jeżeli nie prowadzą działalności gospodarczej,

3) osoby fizyczne, spółki cywilne osób fizycznych, spółki jawne osób fizycznych oraz spółki partnerskie, jeżeli przychody netto tych jednostek ze sprzedaży towarów, produktów i operacji finansowych wyniosły równowartość w walucie polskiej nie mniej niż 1200000 euro i nie więcej niż 2000000 euro za poprzedni

Rady 2006/43/WE oraz uchylająca dyrektywy Rady 78/660/EWG i 83/349/EWG, Dz.U.UE.L. 2013 nr 182 , s. 19.

${ }^{5}$ Dyrektywa Parlamentu Europejskiego i Rady 2013/34/UE...

${ }^{6}$ Ustawa z 29 września 1994 r. o rachunkowości... 
rok obrotowy, a w wypadku jednostek rozpoczynających działalność albo prowadzenie ksiąg rachunkowych w sposób określony ustawą - w roku obrotowym, w którym rozpoczęły działalność albo prowadzenie ksiąg rachunkowych w sposób określony ustawą.

$\mathrm{Z}$ przytoczonych definicji wynika, że $\mathrm{w}$ rozumieniu prawa polskiego pod pojęciem mikrojednostek rozumie się szerszy zakres podmiotów niż wynika to $\mathrm{z}$ uregulowań unijnych. Jest to zrozumiałe, ponieważ poszczególne państwa członkowskie Unii Europejskiej w swoich uregulowaniach prawnych mają prawo - i z niego korzystają - do uszczegółowienia przepisów unijnych, jeżeli tylko te nie stoją $\mathrm{W}$ sprzeczności $\mathrm{z}$ uregulowaniami UE.

\section{ZAWARTOŚC INFORMACYJNA SPRAWOZDANIA FINANSOWEGO MIKROJEDNOSTEK}

Dyrektywa 2013/34/UE ${ }^{7}$ określa, że roczne sprawozdanie finansowe stanowi złożoną całość składającą się, w wypadku każdej jednostki, z co najmniej następujących elementów: bilansu, rachunku zysków i strat oraz informacji dodatkowej do sprawozdania finansowego, poprzedzone ogólnymi informacjami, takimi jak między innymi nazwa jednostki.

Postać bilansu sprowadza się do prezentacji pozycji oznaczonych literami we wzorze bilansu określonego w załącznikach III lub IV do dyrektywy, o ile dane pozycje mają zastosowanie, czyli w wypadku dotyczącym ujęcia w ewidencji księgowej wartości, które należy wykazać w tych pozycjach. Postać bilansu dla mikrojednostek przewidziana przez dyrektywę przedstawiono w tabeli 1 .

Tabela 1. Wzór bilansu dla mikrojednostek

\begin{tabular}{|l|l|}
\hline \multicolumn{1}{|c|}{ Aktywa } & \multicolumn{1}{c|}{ Pasywa } \\
\hline A. Aktywa trwałe & A. Kapitał własny \\
B. Aktywa obrotowe & B. Rezerwy na zobowiązania \\
& $\begin{array}{l}\text { C. Zobowiązania } \\
\text { D. Rozliczenia międzyokresowe kosztów i } \\
\text { przychodów }\end{array}$ \\
\hline Aktywa razem: & Pasywa razem: \\
\hline
\end{tabular}

Źródło: Opracowanie własne na podstawie: Dyrektywy Parlamentu Europejskiego i Rady 2013/34/UE z 26 czerwca 2013 r. w sprawie rocznych sprawozdań finansowych, skonsolidowanych sprawozdań finansowych i powiązanych sprawozdań niektórych rodzajów jednostek, zmieniająca dyrektywę Parlamentu Europejskiego i Rady 2006/43/WE oraz uchylająca dyrektywy Rady 78/660/EWG i 83/349/EWG, Dz.U.UE.L. 2013 nr 182.

W przedstawionym bilansie mikrojednostki prezentuja bardzo ograniczony zakres informacji. Dyrektywa 2013/34/UE ${ }^{8}$ pozwala również mikrojednostkom pominąc informację dotyczącą rozliczeń międzyokresowych kosztów i przychodów, co dodatkowo ogranicza obligatoryjny zakres ujawnień w bilansie.

W wypadku rachunku zysków i strat przepisy te pozwalają na prezentację skróconego rachunku zysków i strat, który wykazuje oddzielnie następujące pozycje, o ile wystapiły w danej mikrojednostce:

${ }^{7}$ Art. 4, ust. 1 Dyrektywy Parlamentu Europejskiego i Rady 2013/34/UE...

${ }^{8}$ Art. 36, ust. 1 Dyrektywy Parlamentu Europejskiego i Rady 2013/34/UE... 
1) przychody netto ze sprzedaży,

2) pozostałe przychody,

3) koszt surowców i materiałów,

4) koszty osobowe,

5) korekty wartości,

6) pozostałe koszty,

7) podatki,

8) zysk lub strata.

W informacji dodatkowej do sprawozdania finansowego wszystkie jednostki ujawniają następujące informacje, jeżeli informacje te wystąpiły ${ }^{9}$ :

a) przyjęte zasady polityki rachunkowości,

b) zmiany w kapitale $\mathrm{z}$ aktualizacji wyceny, w wypadku gdy aktywa trwałe są wyceniane według wartości zaktualizowanej,

c) założenia do wyceny oraz zmiany dokonane, w wypadku gdy instrumenty finansowe lub składniki aktywów niebędące instrumentami finansowymi są wyceniane według wartości godziwej,

d) całkowitą kwotę wszelkich zobowiązań finansowych, gwarancji i poręczeń lub zobowiązań warunkowych nieuwzględnionych w bilansie, ze wskazaniem charakteru i formy wierzytelności zabezpieczonych rzeczowo, wszelkie zobowiązania dotyczące emerytur oraz jednostek powiązanych lub stowarzyszonych są ujawniane odrębnie,

e) kwotę zaliczek i kredytów udzielonych członkom organów administrujących, zarządzających i nadzorujących, ze wskazaniem oprocentowania, głównych warunków oraz wszelkich kwot spłaconych, odpisanych lub umorzonych, a także zobowiązań zaciągniętych w ich imieniu tytułem gwarancji i poręczeń wszelkiego rodzaju, ze wskazaniem kwoty ogółem dla każdej kategorii,

f) kwotę i charakter poszczególnych pozycji przychodów lub kosztów o wyjątkowej wielkości lub nadzwyczajnym charakterze,

g) kwoty zobowiązań finansowych jednostki, które staną się wymagalne po upływie ponad pięciu lat, oraz wszystkie wierzytelności jednostki zabezpieczone rzeczowo przez jednostkę, ze wskazaniem charakteru i formy zabezpieczenia,

h) średnią liczbę zatrudnionych w roku obrotowym.

Dodatkowo dyrektywa zawiera możliwość zwolnienia mikrojednostek z obowiązku sporządzania informacji dodatkowej, jeżeli wszelkie wymagane informacje zostaną ujawnione w przypisach do bilansu. Zawartość merytoryczna poszczególnych elementów sprawozdania finansowego dla mikrojednostek odznacza się większym stopniem syntetyczności niż w wypadku sprawozdań finansowych innych jednostek, prowadzących działalność gospodarczą w większym rozmiarze. Podstawowym argumentem przemawiającym na korzyść takiej szczegółowości prezentowanych informacji jest jej dostosowanie do rozmiarów prowadzonej działalności.

$\mathrm{W}$ ustawie o rachunkowości ${ }^{10}$ podejście do zakresu prezentacji informacji w sprawozdaniu finansowym mikrojednostek jest bardzo podobne. Jednak występują istotne różnice, które powodują konieczność zaprezentowania tych sprawozdań w celu porównania ich zakresu informacyjnego.

${ }^{9}$ Art. 16, ust. 1 Dyrektywy Parlamentu Europejskiego i Rady 2013/34/UE...

${ }^{10}$ Ustawa z 29 września 1994 r. o rachunkowości... 
Ustawa o rachunkowości określa, że w zakres sprawozdania finansowego mikrojednostki wchodzą:

1) informacja ogólna,

2) bilans,

3) informacje uzupełniające do bilansu,

4) rachunek zysków i strat.

Informacje ogólne powinny zawierać dane, które dotyczą prezentacji:

1) firmy, siedziby i adresu albo miejsca zamieszkania i adresu oraz numeru we właściwym rejestrze sądowym lub ewidencji,

2) wskazania czasu trwania działalności jednostki, jeżeli jest ograniczony,

3) wskazania okresu objętego sprawozdaniem finansowym,

4) wskazania zastosowanych zasad rachunkowości przewidzianych dla jednostek mikro z wyszczególnieniem wybranych uproszczeń,

5) wskazania, czy sprawozdanie finansowe zostało sporządzone przy założeniu kontynuowania działalności gospodarczej przez jednostkę $\mathrm{w}$ dającej się przewidzieć przyszłości oraz czy nie istnieją okoliczności wskazujące na zagrożenie kontynuowania przez nią działalności,

6) omówienia przyjętych zasad (polityki) rachunkowości, w tym metod wyceny aktywów i pasywów (także amortyzacji), pomiaru wyniku finansowego oraz sposobu sporządzenia sprawozdania finansowego w zakresie, w jakim ustawa pozostawia jednostce prawo wyboru.

Część informacji prezentowanych $\mathrm{w}$ tej części polskiego sprawozdania finansowego mikrojednostek ma odzwierciedlenie $\mathrm{w}$ informacji dodatkowej wynikającej $\mathrm{z}$ przepisów międzynarodowych.

Bilans w sprawozdaniu finansowym mikrojednostki według ustawy o rachunkowości zaprezentowano w tabeli 2.

Tabela 2. Wzór bilansu dla mikrojednostek

\begin{tabular}{|l|l|}
\hline \multicolumn{1}{|c|}{ AKTYWA } & \multicolumn{1}{c|}{ PASYWA } \\
\hline A. Aktywa trwałe, w tym środki trwałe & A. Kapitał (fundusz) własny, w tym: \\
B. Aktywa obrotowe, w tym: & - kapitał (fundusz) podstawowy \\
& - należne wpłaty na kapitał podstawowy \\
- zapasy & (wielkość ujemna) \\
& B. Zobowiązania i rezerwy na zobowiązania, w \\
& $\begin{array}{l}\text { tym: } \\
- \text { rezerwy na zobowiązania } \\
\end{array}$ \\
& $\begin{array}{l}\text { - zobowiązania z tytułu kredytów i } \\
\text { pożyczek }\end{array}$ \\
\hline Aktywa razem: & Pasywa razem: \\
\hline
\end{tabular}

Źródło: Opracowanie własne na podstawie: Ustawa z 29 września 1994 r. o rachunkowości DzU 2013, poz. 330 ze zm.

Postać tego wzoru bilansu jest obszerniejsza od tego, który jest wymagany przez przepisy międzynarodowe.

Z kolei informacje dodatkowe, które w ustawie o rachunkowości przyjmują nazwę informacji uzupełniających do bilansu, powinny zawierać:

1) kwotę wszelkich zobowiązań finansowych, w tym $z$ tytułu dłużnych instrumentów finansowych, gwarancji i poręczeń lub zobowiązań warunkowych 
nieuwzględnionych w bilansie, ze wskazaniem charakteru i formy wierzytelności zabezpieczonych rzeczowo; wszelkie zobowiązania dotyczące emerytur oraz jednostek powiązanych lub stowarzyszonych są ujawniane odrębnie,

2) kwotę zaliczek i kredytów udzielonych członkom organów administrujących, zarządzających i nadzorujących, ze wskazaniem oprocentowania, głównych warunków oraz wszelkich kwot spłaconych, odpisanych lub umorzonych, a także zobowiązań zaciągniętych w ich imieniu tytułem gwarancji i poręczeń wszelkiego rodzaju, ze wskazaniem kwoty ogółem dla każdej kategorii,

3) udziały (akcje) własne, w tym:

a) przyczyny nabycia udziałów (akcji) własnych dokonanego w roku obrotowym,

b) liczbę i wartość nominalną nabytych oraz zbytych w roku obrotowym udziałów (akcji), a w wypadku braku wartości nominalnej, ich wartość księgową, jak też część kapitału podstawowego, którą te udziały (akcje) reprezentuja,

c) w wypadku nabycia lub zbycia odpłatnego - równowartość tych udziałów (akcji),

d) liczbę i wartość nominalną lub - w razie braku wartości nominalnej - wartość księgową wszystkich udziałów (akcji) nabytych i zatrzymanych, jak również część kapitału podstawowego, którą te udziały (akcje) reprezentują.

Wzór ostatniego elementu sprawozdania finansowego mikrojednostek, czyli rachunku zysków i strat w wersji minimalnej, określony jest w postaci:

A. Przychody podstawowej działalności operacyjnej i zrównane z nimi, w tym:

- zmiana stanu produktów (zwiększenie - wartość dodatnia, zmniejszenie wartość ujemna),

B. Koszty podstawowej działalności operacyjnej:

I. Amortyzacja,

II. Zużycie materiałów i energii,

III. Wynagrodzenia, ubezpieczenia społeczne i inne świadczenia,

IV. Pozostałe koszty,

C. Pozostałe przychody i zyski, w tym aktualizacja wartości aktywów,

D. Pozostałe koszty i straty, w tym aktualizacja wartości aktywów,

E. Podatek dochodowy,

F. Zysk/strata netto $(\mathrm{A}-\mathrm{B}+\mathrm{C}-\mathrm{D}-\mathrm{E})$

(dla jednostek mikro nieprowadzących działalności gospodarczej) lub

G. Wynik finansowy netto ogółem $(\mathrm{A}-\mathrm{B}+\mathrm{C}-\mathrm{D}-\mathrm{E})$, w tym:

I. Nadwyżka przychodów nad kosztami (wartość dodatnia),

II. Nadwyżka kosztów nad przychodami (wartość ujemna).

Również w wypadku rachunku zysków i strat zakres ujawnień wynikający z ustawy o rachunkowości jest szerszy niż w rachunku zysków i strat unormowanym przez dyrektywę Unii Europejskiej. A zatem można stwierdzić, że sprawozdania finansowe mikrojednostek zarówno w normach polskich, jak i zagranicznych niewiele się od siebie różnią. Potwierdza to również podobne potraktowanie sprawozdania mikrojednostek w Międzynarodowych Standardach Sprawozdawczości Finansowej ${ }^{11}$. Zasady te także

11 Międzynarodowy Standard Sprawozdawczości Finansowej dla Matych $i$ Średnich Przedsiębiorstw, IASCF, SKwP, KIBR, Warszawa 2011. 
niewiele się różnią od tych zawartych w ustawie o rachunkowości i dyrektywie 2013/34/UE.

\section{OCENA MOŻLIWOŚCI WYKORZYSTANIA INFORMACJI ZAWARTYCH W SPRAWOZDANIACH FINANSOWYCH MIKROJEDNOSTEK}

$\mathrm{Z}$ powodu niedużych różnic $\mathrm{w}$ konstrukcji i zakresie ujawnień $\mathrm{w}$ sprawozdaniach finansowych mikrojednostek uregulowanych w przepisach międzynarodowych i krajowych dalsza część rozważań koncentrować się będzie na sprawozdaniu finansowym mikrojednostki, które zostało przedstawione w ustawie o rachunkowości.

Ustawodawca dał organom zatwierdzającym w mikrojednostkach możliwość wyboru sporządzania sprawozdania finansowego według załącznika 4 lub załącznika 1 ustawy o rachunkowości $\mathrm{i}$ to $\mathrm{z}$ możliwością ich rozszerzenia. $\mathrm{W}$ istotny sposób wpływa to na pojemność informacyjną sprawozdań finansowych sporządzanych w mikrojednostkach. A zatem wiąże się z tym, które jednostki gospodarcze będą skłonne skorzystać z daleko idących uproszczeń, dotyczących sprawozdawczości finansowej, a oferowanych przez załącznik 4 ustawy o rachunkowości.

Wydaje się, że w wielu jednostkach gospodarczych prowadzonych w mniejszym rozmiarze sprawozdawczość finansowa traktowana jest jako przykry obowiązek formalny, który nie wiadomo dlaczego, został zawarty w ustawie o rachunkowości. Cały dział księgowy traktowany jest jako miejsce powstawania kosztów, które nie generuje dla przedsiębiorstwa żadnej wartości dodanej, poza koniecznym ustaleniem dochodu do opodatkowania, który to obowiązek powstaje na podstawie odrębnych przepisów niewynikających z ustawy o rachunkowości ${ }^{12}$. A zatem - czy prowadzenie rachunkowości w takich jednostkach ma sens, jeżeli sprawozdania finansowego nikt nie czyta, nie analizuje i nie wyciąga na jego podstawie wniosków. Może warto, w sytuacji kiedy ustawodawca uzasadnia wprowadzone zmiany dotyczące mikrojednostek ułatwieniami dla przedsiębiorców, rozważyć dokonanie rzeczywistego uproszczenia i wyłączenia z obowiązku stosowania ustawy o rachunkowości tych jednostek, które nie spełniają warunków 64 artykułu ustawy o rachunkowości. W artykule tym przedstawiono jednostki, których roczne sprawozdanie finansowe podlega obligatoryjnemu badaniu przez biegłego rewidenta. W jednostkach, które nie spełniają wymogów tego artykułu, w świetle obowiązujących przepisów nigdy nie dokonuje się badania sprawozdania. W tej sytuacji pojawia się pytanie, co powoduje, że w tych jednostkach prowadzona jest rachunkowość na zasadach ustalonych przez ustawę o rachunkowości, a nie według zasad podatkowych.

Jedną z możliwych odpowiedzi może być stwierdzenie, które wskazuje na możliwości zarządczego wykorzystania informacji płynących ze sprawozdania finansowego. Te potrzeby usprawiedliwiają zdecydowanie szerszy zakres ujawnień w sprawozdawczości finansowej niż w ewidencjach podatkowych. Najbardziej rozwiniętą formą ewidencji podatkowych jest Podatkowa księga przychodów i rozchodów ${ }^{13}$, która przychody prezentuje w dwóch kategoriach, a koszty w czterech. Przez wielu jej użytkowników

${ }^{12}$ Obowiązek ten wynika z ustawy z 15 lutego 1992 r. o podatku dochodowym od osób prawnych DzU 2014, poz. 851 ze zm. lub ustawy z 26 lipca 1991 r. o podatku dochodowym od osób fizycznych DzU 2012, poz. 361 ze zm.

${ }^{13}$ Rozporząqzenie Ministra Finansów z 26 sierpnia 2003 r. w sprawie prowadzenia podatkowej księgi przychodów i rozchodów DzU 2014, poz. 1037 ze zm. 
uważana jako zupełnie niewystarczająca dla celów zarządczych, z powodu ubogiego zakresu informacyjnego.

$\mathrm{W}$ takim razie należy się zastanowić, czy uproszczenia w sprawozdawczości finansowej dotyczące nowo wprowadzonych mikrojednostek zmierzają w dobrą stronę. Czy może jest to zmiana ilościowa, a nie jakościowa. Przecież w dobie powszechnego wykorzystywania systemów informatycznych do ewidencji księgowej sporządzenie nawet rozbudowanego sprawozdania finansowego nie nastręcza relatywnie większego problemu.

W bilansie mikrojednostki aktywa przedstawiane są w trzech kategoriach: środki trwałe, bez uwzględnienia środków trwałych w budowie i zaliczek na nie, zapasy oraz należności krótkoterminowe. W aktywach trwałych nie ma wyodrębnienia należności długoterminowych, a w aktywach obrotowych brak niezwykle istotnej pozycji dotyczącej należności z tytułu dostaw i usług, która powinna być wyodrębniona z pozycji należności krótkoterminowe. W pasywach wręcz zdumiewa brak pozycji wynik finansowy, który co prawda, można odczytać z rachunku zysków i strat, ale taka sama wartość wyniku finansowego w bilansie oraz rachunku zysków i strat jest formą kontroli poprawności sporządzenia sprawozdania finansowego oraz istotną informacją dotyczącą jego stosunku do kapitałów własnych, kapitałów ogółem czy aktywów.

Braki te nie są uzupełnione w informacji uzupełniającej. Informacja uzupełniająca wymaga ujawniania danych dotyczących zobowiązań finansowych, gwarancji, poręczeń, kredytów, zaliczek udzielanych członkom organów stanowiących w jednostce, czy o udziałach lub akcjach własnych. Watpliwe wydaje się powszechne występowanie tych danych w jednostkach mikro, które przecież działalność gospodarczą prowadzą w niewielkim zakresie.

Rachunek zysków i strat zaczyna wartość, którą ustala się umownie poprzez dokonanie korekty przychodów ze sprzedaży produktów, towarów i materiałów o różnicę między stanem zapasów produktów i czynnych oraz biernych rozliczeń międzyokresowych kosztów na początek i koniec roku oraz odjęcia kosztów wytworzenia produktów na własne potrzeby. Takie podejście do prezentacji jednej z najistotniejszych pozycji, jaką jest przychód ze sprzedaży produktów lub towarów, wydaje się niewłaściwe. Tak zagregowane informacje o przychodach są mało przydatne do ich analizy. Koszty prezentuje się w scalonej wersji, dotyczącej tylko kluczowych kosztów, co samo w sobie jest istotną informacją, lecz w celach zarządczych zbyt ubogą.

\section{WNIOSKI}

Podsumowując, należy stwierdzić, że zmiany te chociaż oczekiwane przez przedsiębiorców, którzy w rzeczywistości nie korzystają z informacji zawartych w sprawozdaniach finansowych, nie są zmianami optymalnymi. Przydatność zarządcza tak skonstruowanych sprawozdań finansowych jest znikoma. A zatem dla celów zarządczych jednostki spełniające warunki zakwalifikowania ich do jednostek mikro powinny rozważyć możliwość sporządzania sprawozdania finansowego według załącznika 1 do ustawy o rachunkowości lub istotnego rozwinięcia zakresu informacyjnego sprawozdania finansowego dla mikrojednostki. Zapewne lepszym rozwiązaniem byłoby zwolnienie większej liczby jednostek gospodarczych z obowiązku prowadzenia rachunkowości na rzecz ewidencji podatkowych niż komplikowanie zasad rachunkowości przez wprowadzanie kolejnej kategorii jednostek, których sprawozdanie finansowe i tak przecież nie jest kontrolowane przez biegłych rewidentów pod kątem zgodności z ustawą o rachunkowości. 


\section{LITERATURA}

[1] Dyrektywa Parlamentu Europejskiego i Rady 2013/34/UE z 26 czerwca 2013 r. w sprawie rocznych sprawozdań finansowych, skonsolidowanych sprawozdań finansowych i powiązanych sprawozdań niektórych rodzajów jednostek, zmieniająca dyrektywę Parlamentu Europejskiego i Rady 2006/43/WE oraz uchylająca dyrektywy Rady 78/660/EWG i 83/349/EWG, Dz.U.UE.L. 2013 nr 182, s. 19.

[2] Międzynarodowy Standard Sprawozdawczości Finansowej dla Matych i Średnich Przedsiębiorstw, IASCF, SKwP, KIBR, Warszawa 2011.

[3] Rozporządzenie Ministra Finansów z 26 sierpnia 2003 r. w sprawie prowadzenia podatkowej księgi przychodów i rozchodów DzU 2014, poz. 1037 ze zm.

[4] Sprawozdanie finansowe wedtug polskich $i$ międzynarodowych standardów rachunkowości, red. G.K. Świderska, W. Więcław, Difin, Warszawa 2012, s. 60.

[5] Ustawa z 15 lutego 1992 r. o podatku dochodowym od osób prawnych DzU 2014, poz. 851 ze zm.

[6] Ustawa z 26 lipca 1991 r. o podatku dochodowym od osób fizycznych DzU 2012, poz. 361 ze zm.

[7] Ustawa z 29 września 1994 r. o rachunkowości DzU 2013, poz. 330 ze zm.

\section{INFORMATIONAL VALUES OF FINANCIAL STATEMENTS OF THE MICRO ENTITIES}

The financial result is a basic measure of the efficiency of doing business. To effectively manage financial results, information on the elements affecting this form and change is essential. This information is information about income and expenses. People who are outsiders, and are interested in information about the financial position, results of operations and changes in financial position of the entity are doomed to the use of this information, which will provide them the entity. Synthetic collection of elements of the financial results is the financial statement. The task of the financial statements of a business entity is to inform interested stakeholders and people of financial position, about the results of operations and changes in financial position of the entity. The amendment to the Accounting Act introduced the concept of micro units and a new simplified model of financial statements for these types of units. This change is intended to bring the detail of the information presented in the financial statement to the size of business. The financial statements of micro-entities are highly simplified. This results in a significant decrease in value of information on these statements. The problem that arises is the ability to meet the information needs of different recipients of such financial statements. The aim of this article is to undergo a brief analysis of the scope of the disclosure of the information contained in the financial statements micro entities and their use for the purpose of management.

Keywords: financial statements, micro unit, accounting.

DOI:10.7862/rz.2014.hss.59

Przesłano do redakcji: październik 2014

Przyjęto do druku: grudzień 2014 